\title{
The Implicature of Begalan Tradition as an Effort to Develop a Good Character in the Community in Banyumas Central Java
}

\author{
Eko Suroso \\ Universitas Muhammadiyah Purwokerto \& \\ Universitas Sebelas Maret Surakarta \\ Jawa Tengah, Indonesia \\ ekosuroso36@gmail.com
}

\author{
Kundharu Saddhono \\ Universitas Sebelas Maret Surakarta \\ Jawa Tengah, Indonesia \\ kundharu.uns@gmail.com
}

\author{
Sumarlam, \\ Universitas Sebelas Maret Surakarta \\ Jawa Tengah, Indonesia \\ sumarlamwd@gmail.com
}

\begin{abstract}
The implicature of Begalan tradition is very effective to develop a good character in Banyumas community. The research problem of this study is "what are the implicatures in Begalan tradition which can develop a good character in Banyumas community?" This study was conducted with a qualitative descriptive approach. The data were collected through non-participant observation and interview. The data analysis was completed by describing the Begalan tradition in Banyumas and explaining the implicature of Begalan tradition which shows the efforts to develop the character of the community in Banyumas, Indonesia. The result of this study indicates that in the Begalan tradition there is a conventional and conversational implicates that can be developed to create some good characters such as: religious, tolerant, discipline, hardworking, creative, independent, democratic, appreciative, friendly, peace-loving, caring, and responsibility.
\end{abstract}

Keywords: implicature, Begalan Tradition, Good Character

\section{INTRODUCTION}

There are two ways to build a good communication with others, i.e, direct and indirect communication. Direct communication is a face-to-face communication, whereas indirect communication is a long-distance communication through a media, as stated by Nugraheni [1] indirect communication is usually done using media, such as a phone or a letter. The direct and indirect communication in certain meaning or message always occursexplicitly and implicitly. Implicature is appropriate for character development because good character will emerge from the implicit meaning rather than the explicit one,

The Begalan tradition contains an implicit meaning. Angkring is a symbol of independence of a family that can stand alone or independent. Both pairs of angkring legs are symbols of husband and wife who are able to support all the needs and burdens sincerely. Similarly, ubarampe, which is carried by angkring, also contains implicature which is very appropriate for the development of human character in general and adult in particular. This is also stated by Chusmeru[2], Begalan contains a message to remove bajang sawane kaki penganten lan nini penganten (the leg of the bride and groom). Based on Chusmeru, it is well known that there is an implicature in Begalan traditional in Banyumas. This research aimsat answering the question: what are the implicatures in Begalan tradition which can develop a good character in Banyumas community?

\section{LITERATURE REVIEW}

The Begalan tradition is one of the hallmarks of the Banyumas bridal ceremonies which include marriage advice to the bride who is symbolically presented and visualized in a form of drama fragments performed by two players. One person portrays himself as the envoy of the bridegroom who carries angkring while the other player serves as mbegal bajang sanwe kaki pengantennini penganten (the bride who is in charge of "cheating on the leg of the bridesmaid"). Inside angkringan there are household appliances that supply both gowns. According to Supriyadi [3] the meaning of begalan is also known as sambekalanipun, which means being kept away from all kinds of dangers.

The implicature term is used by Grice in 1967 to address the problem of the meaning of the language that cannot be solved by ordinary semantic theory [4]. Grice [5] says that the implicature divided into two, namely conventional implicature and conversational implicature. In order for the implicatureto be well understood, it is necessary that the principle of cooperation among the speakers exist. Grice [6] says that the principle of cooperation is divided into four maxims, namely (a) Maxim of Quality, (b) Maxim of Quantity, (c) Maxim of Relevance, And (d) Maxim of Manner.

\section{RESEARCH METHOD}

This study was conducted using a qualitative descriptive approach. In conducting a descriptive approach, the researchers describe, explain, and present the data as it is. In conducting a qualitative approach, researchers interpret to understand the implicative meaning of the research data.

This research data is Begalan in Sokaraja, Banyumas Regency. The technique of taking the data was completed by non-participant observation and interview. 
In this case, researchers were not involved in Begalan, rather as observers and interviewers. Observation techniques were conducted by looking directly at how Begalan tradition was performed in Sokaraja Banyumas. In the interview, the researchers interviewed the performers, organizers, and audiences as well. The data analysis was performed by describing the tradition, interpreting the various tools used in the shows, and finally determining the implicature.

\section{DISCUSSION}

\section{Begalan Tradition in Banyumas Central Java}

Begalanis an art coming fromBanyumasand has a long history. Begalan was created by RadenTumenggung Yudanegara IV around the 1750s. The art that was originally created to dispose of himself as the Mayor of Banyumas, has now become part of the Banyumas culture associated with the wedding ceremony [7]. Begalan is now a culture of Banyumas for generations and believed by the community. Begalan can be called as a form of culture, both material and non-material.

The Begalan comes from the word "Javanese" word 'Begal' which means a robber or force to abduct someone in the middle of a journey. Mbegal or begalan means mimicking the way robbers intrude a person's journey. In the former area of Banyumas regency, Begalan was known as a stage performance with the mission of giving a wedding advice for the bride. Budiono Herusatoto[8] explains that Begalan began to be performed on stage after Raden Tumenggung Yudanegara IV was removed from his position as the Prince of Banyumas by the British government. Raden Tumenggung Yudanegara IV as the 10th Prince of Banyumas inspired Banyumas to be self-sufficient (taxfree) or to become an autonomous area-no longer under Surakarta Kingdom. At that time, the Kingdom was a subordinate government of the Dutch colonist. For Surakarta kingdom, these ideals were considered mbalelo-betrayal; so they reported to the GovernorGeneral of the Netherlands. As results, RadenTumenggungYudanegara got dethroned from his position and became Mantri Anom.

The Governor-General of the Netherlands also established his successor, Raden Tumenggung Yudanegara $\mathrm{V}$ as the 11th Prince of Banyumas. According to the story [9], Raden Tumenggung Yudanegara IV prayed and eventually got the inspiration to create Begalan. Begalanwas meant as a means for selfpurification with the aim of removing the bad luck and overcame it to regain happiness and peace, both for himself and for his grandchildren.

\section{The Meaning of the Tools in Begalan's Tradition in Banyumas Central Java \\ Begalan tradition uses various devices. In} Banyumas, these various tools are called ubarampe. Thistool is a medium that stores symbolic messages. Ubarampe is a kitchen tool that is entirely made of bamboo, wood, and coconut shell. The types of rampeare: pari and palawija, tepas, kukusan, irus, cething, siwur, enhtong, layah and ulegan, talenan, and dingklik. The whole ubarampe are hung on a stretch of bamboo from a double-legged bamboo. Angkring is a symbol of independence of a family that can stand alone. Both pairs of angkring legs are symbols of husband and wife who can support all needs and share the burden. Pari (rice) and palawija (various tubers) symbolize the Dewi Sri, Goddess of fertility and prosperity. Tepas (fan) has two meanings, i.e. something that can be used as light and something that can also be used to raise or stir the fireplace in the kitchen. Irus serves to flatten or stir the cooked vegetables in order to spice evenly. It contains a message that things should be processed (twisted). Layah and ulegan symbolize lingga (male / husband) and yoni (woman / wife) respectively. Cething or rice basket is a fortune symbol. Kukusan is the place where rice is cooked. This is a reflection of the heat of life's turbulence so it is not to be directly grounded as it is, but take it as steam (the implied meaning of the turbulence) [10]. Siwur or dipper serves to water or rinse (creating a cool atmosphere).

\section{Development of Character Values through Begalan Tradition Implicature}

Begalan literally means to abduct someone on the way. In the context of Begalan tradition, it has the same meaning as the word 'steal'ingeneral. It is not the property, rather the bridle of the bridegroom and the grandfather of the bride and groom (bajangsawan kaki penganten and nini penganten). Bajangsawan is a form of religious character development. The religious attitude referred in this case is the attempt to prevent others from losing bad luck or getting harm. The tool has a sense of independence. Someone who has a family should have a self-reliant attitude. This independence implicatively develops independent character and responsibility. The independent character of this opportunity is independence in all respects namely personality, social, and economic independence. A person who hasa family by himself will be required to be independent as a form of personal responsibility. Thus, the symbol of angkring is able to develop the character of self-reliance and character of responsibility.

Pari has a fertility meaning. This symbol is highly possible to develop a caring environmental character. Someone who does not care about the environment will not be able to create fertility. Palawija means prosperity, which implicatively is capable of developing a character of democracy, friendship, and peace of mind. In a marriage life, one should be democratic in solving various issues. In order for this democracy to work well, one needs to develop friendly characters because democracy without friendship will cause discomfort. If someone has a friendly character, he/she will bring a character of loving-peace. The meaning of tepas implies an implicature for the character development of the loving-peace as well as reconciliation to cool down the atmosphere. The symbol of the irus that contains the message of well thinking has been imperative to develop 
the creative character. Layah and ulegan that symbolize lingga (male / husband) and yoni (woman / wife) are implicated in the development of friendly and communicative characters. Husband and wife should be like friends. In order for friendship to last long, both parties need to develop communication characters. Cething or rice basket which is a symbol of a fortunetelling implies a character of honesty; it means that in order to gain livelihood, honesty is needed. Kukusan that has the meaning of intimacy shows implicature for the development of creative characters because only the creative ones are able to take the implied food of something real. Siwur or dipper that serves to water or flush (create a cool atmosphere) implies the development of love of homeland character because if someone loves the homeland, then the homeland will provide comfort or coolness in one's heart.

\section{CONCLUSION}

The Begalan tradition means the unfortunatebride and groom (bajangsawan kaki penganten and nini penganten). The implicature of the development of the character is tradition in the religious character. Meanwhile, angkring has a sense of independence. The implicature of character development contained in this instrument is independence and responsibility. Pari has a fertility symbol. The character development implicature in pariis the environmental care character. Palawijais a symbol of prosperity; it implicatively show that someone is capable of developing a character of democracy, friendship, and peace of mind. The meaning of tepa simplies the development of the character of the love of peace as well as reconciliation to cool down atmosphere. Irus contains a message for the development of creative characters. Layah and ulegan that symbolize lingga (male/husband) and yoni (woman/wife) are implicated in the development of friendly and communicative characters. Cething or rice basket which is a symbol of a fortune-telling tool implies the character of honesty, meaning that in order to obtain the livelihood, one should live honestly. Kukusan that has the meaning of development of creative characters because only creative people who are able to take the implied food. Siwur or dipper that serves to water or flush (creating a cool atmosphere) implies the development of love of homeland characters because simply by loving the homeland, the comfort or coolness in the heart can be obtained.

\section{REFERENCES}

[1] Chusmeru. Begalan sebagai Komunikasi Tradisional Banyumas: Studi Deskriptif Komponen Komunikasi dalam Kesenian Begalan (Begalan as a Banyumas traditional communication: The descriptive componen study of communication in the art of Begalan). ActadiurnA, VII, 2, 1-8 9. 2011
[2] Grice, H.P. Logic and Conversation. Syntax and Semantics, 3, 41-58. 1975.

[3] Habisch, A. \& Bachmann, C. Empowering practical wisdom from religious traditions: a ricoeuri an approach. International Journal of Corporate Social Responsibility, 1 (10), 19.Lubis, H. H. (2011). Analisis Wacana Pragmatik (Pragmatic discource analysis). Medan: Angkasa Bandung. 2016.

[4] Herusatoto, B. Banyumas, Sejarah, Budaya, Bahasa, danWatak. PT LKiS Pelangi Aksara: Yogyakarta. 2008.

[5] Liliweri, A. Makna Budaya dalam Komunikasi Antar Budaya (Cultural Meaning in Intercultural Communications). Yogyakarta: PT LKiS Printing Cemerlang. 2009.

[6] Nugraheni, Y. Analisis Implikatur Pada Naskah Film Harry Potter And The Goblet Of Fire (Implicatur analysis on Harry Potter and The Goblet of Fire script). Prosiding Seminar NasionalUnimus, 390-397. 2010.

[7] Priyadi, S. Sejarah Purwokerto (History OfPurwokerto Town. Humaniora, 9 (1), 106-118. 2008.

[8] Setiawan, A., T., F. Alih Fungsi Tradisi Begalan dalam Adat Perkawinan Banyumas: Studi Tentang Eksistensi Tradisi Begalan dalam Masyarakat Banyumas (The transfer of Begalan tradition in Banyumas customary marriage: The study of Begalan existence in Banyumas). Jurnal Program Studi Pendidikan Bahasa dan Sastra Jawa_Universitas Muhammadiyah Purworejo, 6 (4), 9-17. 2015.

[9] Tosa, N. Cultural Computing - Creative Power Integrating Culture, Unconscious-ness and Software*. International Federation for Information Processing, 3, 223-232. 2010.

[10] Wijana, I. D. P. \&Rohmadi, M. Analisis Wacana Pragmatik Kajian Teori dan Analisis (Pragmatic Discourse Analysis Theory and Analysis Study). Surakarta: Yuma Pustaka. 2011.

[11] Yule, G. Pragmatik (Pragmatic). Yogyakarta: PustakaPelajar. 2006. 